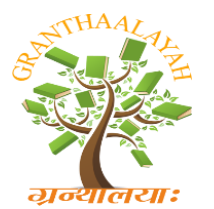

INTERNATIONAL JOURNAL OF RESEARCH -

GRANTHAALAYAH

A knowledge Repository

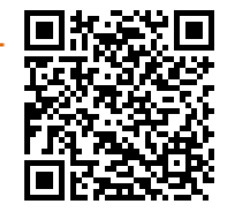

Management

\title{
CUSTOMER COST - SECOND IMPORTANT FACTOR FOR IMAGE GAP ANALYSIS OF LIFE INSURANCE SERVICES - BASED ON THE DATA COLLECTION FROM GUWAHATI
}

\author{
Pankaj Bihani ${ }^{1}$, Prof. Amalesh Bhowal ${ }^{2}$ \\ ${ }^{1}$ Research Scholar, Assam University- Diphu Campus, INDIA \\ ${ }^{2}$ Head of Department, Department of Commerce, Assam University- Diphu Campus, INDIA
}

\begin{abstract}
The concept of Customer Cost was developed by Lauterborn (1990) while developing the customer oriented Marketing Mix- the 4C concept. 4C model replaces the earlier 4Ps of Marketing Mix, here the focus is on customer and the current chapter is all about the second C of this model i.e. Customer Cost or Price in earlier 4P model. The Customer Cost concept is based on the fact that customers are more concerned with the total cost of acquiring a solution of their problem (Product or Service) rather than the price being charged for the Solution (Product or Service) offered by the Company (Moller, 2006), Customer Cost is a assumed to be a better approach as customers are interested in it. price is the quantity of payment or compensation given by one party to another in return for goods or services. In modern economies, prices are generally expressed in units of some form of currency. (For commodities, they are expressed as currency per unit weight of the commodity, e.g. Rs. per kilogram). Although prices could be quoted as quantities of other goods or services this sort of barter exchange is rarely seen. Prices are sometimes quoted in terms of vouchers such as trading stamps and air miles. In some circumstances, cigarettes have been used as currency, for example in prisons, in times of hyperinflation, and in some places during World War 2. In a black market economy, barter is also relatively common. In many financial transactions, it is customary to quote prices in other ways. The most obvious example is in pricing a loan, when the cost will be expressed as the percentage rate of interest. The total amount of interest payable depends upon credit risk, the loan amount and the period of the loan. Other examples can be found in pricing financial derivatives and other financial assets. For instance the price of inflation-linked government securities in several countries is quoted as the actual price divided by a factor representing inflation since the security was issued. Price sometimes refers to the quantity of payment requested by a seller of goods or services, rather than the eventual payment amount. This requested amount is often called the asking price or selling price, while the actual payment may be called the transaction price or traded price. Likewise, the bid price or buying price is the quantity of payment offered by a buyer of goods or services, although this meaning is more common in asset or financial markets than in consumer markets. Price refers to the amount charged for a product or service (Kotler, 2007), from producer's point of view Price generates revenue (Kotler, 2003). Whereas Customer Cost concept not only includes the price of the product but also includes other associated costs in addition to the
\end{abstract}


Price of the product or service (Goi, 2009). Customer Cost means the total expenditure a customer is going to spent for purchasing a Customer Solution. Thus Price represents only a part of total cost or Customer's Cost (Kotler, Armstrong, \& haque, 2012).

Keywords:

Customer Cost, Customer Solution, Life Insurance Services, consumer markets.

Cite This Article: Pankaj Bihani, and Prof. Amalesh Bhowal, "CUSTOMER COST - SECOND IMPORTANT FACTOR FOR IMAGE GAP ANALYSIS OF LIFE INSURANCE SERVICES BASED ON THE DATA COLLECTION FROM GUWAHATI" International Journal of Research - Granthaalayah, Vol. 4, No. 3 (2016): 124-130.

\section{INTRODUCTION}

In the context of Life Insurance, the price of a ULIP is determined by the offer price or NAV (Net Asset Value), in case of Traditional product price is determined by actuary. Price or Customer Cost is the yardstick and acts as most influential factor in a buying decision. Specially in the context of Life Insurance Price or Premium or Customer Cost plays a vital role both from the point of view of business firm as well as customer. (Yogakshema, Jan, 09) Rangachary, exChairman of IRDA, in his article states that - the principle of differential pricing is necessary to sell products in rural areas.

\section{OBJECTIVE}

To ascertain the gap between the degree of 'Customer Cost Dimension Expected' and the degree of 'Customer Cost Dimension Experienced' of 4C based Marketing Mix with respect to Life Insurance.

\section{HYPOTHESIS}

There is no significant difference between the 'Degree of Customer Cost Dimension Expected' and the 'Degree of Customer Cost Dimension Experienced' of 4C based Marketing Mix with respect to Life Insurance in Guwahati.

\section{DESCRIPTION OF ITEMS FOR MEASURING GAP ANALYSIS ON CUSTOMER COST DIMENSION}

A list of items was identified to measure the degree of Customer Cost Dimension Expected and the degree of Customer Cost Dimension Experienced. The following 27 (Twenty Seven) items (Table No. 4.4) were finally identified and used for the purpose of measuring expectation and experience related to Customer Cost dimension of $4 \mathrm{C}$ based Marketing Mix.

Table 1: Description of the items used in the questionnaire related to Customer Cost

\begin{tabular}{|l|l|}
\hline $\begin{array}{l}\text { Item } \\
\text { No. }\end{array}$ & Description \\
\hline 1 & It requires a continuous outflow of money \\
\hline
\end{tabular}




\begin{tabular}{|l|l|}
2 & Premium calculation in Life Insurance is very complex \\
\hline 3 & $\begin{array}{l}\text { Mode of Premium in Life Insurance is confusing, which one to choose- Annual, Half } \\
\text { Yearly, Quarterly or Monthly }\end{array}$ \\
\hline 4 & Understanding about Direct Debit or ECS(Electronic Clearing System) \\
\hline 5 & Easy to select the premium size for the Life Insurance \\
\hline 7 & The Online Renewal Payment system is very good \\
\hline 8 & Premium related information is readily available \\
\hline 9 & Anline comparison of Premium from other competitors is very easy \\
\hline 10 & Handouts on Cost Of Insurance and other related charges is available \\
\hline 12 & Understanding the costs involved in the premium amount \\
\hline 13 & good. \\
\hline 14 & Able to understand the cost structure of the life insurance products \\
\hline 15 & Understanding about the changes in NAV in respect of ULIP \\
\hline 16 & Thderstanding about the pattern of changes in NAV in respect of ULIP \\
\hline 17 & Easy to calculate the Premium for Endowment plans \\
\hline 18 & It is difficult to understand the buying price fixation mechanism in respect of ULIP. \\
\hline 19 & Confidence about the appropriate buying-time in respect of ULIP. \\
\hline 20 & Confidence about the appropriate buying price in respect of ULIP. \\
\hline 21 & The premium of Term Plans are confusing \\
\hline 22 & Premium amount of ULIP is simple as Sum Assured is multiple of Premium \\
\hline 23 & $\begin{array}{l}\text { Premium multiplication for Sum Assured to avail tax benefit u/s 80C are known to } \\
\text { me in respect to ULIP }\end{array}$ \\
\hline 24 & Having proper Knowledge of Riders \\
\hline 25 & Extra Premium charged due to sub standard age proof are explained properly \\
\hline 26 & $\begin{array}{l}\text { Premium is a factor of Age, as age increases premium increases in case of traditional } \\
\text { plans }\end{array}$ \\
\hline 27 & Premium is independent of Age in respect of ULIP \\
\hline
\end{tabular}

Source: Questionnaire

Respondents were requested to respond to item number 1 to 27 under Questionnaire III in a 5 point scale in respect to their expectations as well as their experiences, to what extent they are agree or disagree with respect to items selected for the study under five categories i.e., Strongly Agree (SA), Agree (A), Neither Agree Nor Disagree (NAND), Disagree (DA), Strongly Disagree (SDA), using tick marks only. Then these categories were assigned scores as Strongly Agree (SA) equals to 2, Agree (A) equals to 1, Neither Agree Nor Disagree (NAND) equals to 0, Disagree (DA) equals to -1 , Strongly Disagree (SDA) equals to -2 , the data so generated were subjected statistical treatment using SPSS. The scores of individual items by a single respondent were totaled. This total represented the 'Degree of Customer Cost Dimension Expected' of that single respondent. Similarly, the total of the 'Degree of Customer Cost Dimension Experience' was derived. 


\section{RELIABILITY STATISTICS OF EXPECTATION AND EXPERIENCE ON CUSTOMER COST DIMENSION}

Reliability denotes the consistency and stability of an instrument. Cronbach's Alpha test was used to measure the reliability of the scales used for measuring the 'Degree of Customer Cost Dimension Expected' and the 'Degree of Customer Cost Dimension Experienced'. The test (Cronbach's Alpha) was calculated using SPSS 20.0 and the results are shown below in Table No. 2. The Cronbach's Alpha coefficient values with respect to all the 27 items (as mentioned in Table No. 2) relating the 'Degree of Customer Cost Dimension Expected' and the 'Degree of Customer Cost Dimension Experienced' were found to be above 0.70. Therefore, the scales used in this study to measure the 'Degree of Customer Cost Dimension Expected' and the 'Degree of Customer Cost Dimension Experienced' were considered as reliably and internally consistent (Nunnaly, 1978; Zikmund, 2008).

Table 2: Reliability statistics of Customer Cost Dimension Expected and Experienced

\begin{tabular}{|l|l|l|l|}
\hline \multicolumn{2}{|l|}{ District Headquarter } & Guwahati & Decision \\
\hline \multirow{2}{*}{$\begin{array}{l}\text { Cronbach's } \\
\text { Alpha }\end{array}$} & Degree of Customer Cost Dimension Expected & .899 & Acceptable \\
\cline { 2 - 5 } & Degree of Customer Cost Dimension Experienced & .896 & Acceptable \\
\cline { 2 - 5 } & Ded from & & \\
\hline
\end{tabular}

Source: Compiled from survey data (Using SPSS 20.0) $N=27$.

\section{NORMALITY TEST OF DATA OF EXPECTATION AND EXPERIENCE ON CUSTOMER COST DIMENSION}

One Sample KS test was used to test the Normality of Distribution of the data relating to the 'Degree of Customer Cost Dimension Expected' and the 'Degree of Customer Cost Dimension Experienced' in respect to each of the areas as well as the overall data. The results of one sample KS Test are shown in Table 3. The test revealed that the data distribution does not follow the Normality of sample Distribution at overall as well as District Headquarter level. This is because the Asymp. Sig. (2-tailed) values of both the Customer Cost Expected and Customer Cost Experienced were found to be less than 0.05 (at $5 \%$ level of significance). From the above analysis it is observed that only non-parametric tests are suitable for studying test of significance of the main hypothesis.

Table 3: One sample KS Test of Customer Cost Dimension Expected and Experienced

\begin{tabular}{|l|l|l|l|}
\hline \multicolumn{2}{|l|}{} & Guwahati \\
\cline { 3 - 4 } \multicolumn{2}{l|}{} & Total of & Total of \\
\multicolumn{2}{|l|}{} & Customer & Customer \\
& & Cost \\
Cost & Expected & Expected \\
\hline N & 1920 & 384 \\
\hline \multirow{2}{*}{ Normal Parameters } & Mean & 6.8938 & 13.6849 \\
\cline { 2 - 4 } & Std. Deviation & 26.04748 & 16.98985 \\
\hline Most Extreme & Absolute & 0.071 & 0.083 \\
\hline
\end{tabular}




\begin{tabular}{|l|l|l|l|}
\hline \multirow{2}{*}{ Differences } & Positive & 0.063 & 0.064 \\
\cline { 2 - 4 } & Negative & -0.071 & -0.083 \\
\hline Kolmogorov-Smirnov Z & 3.114 & 1.623 \\
\hline Asymp. Sig. (2-tailed) & 0 & 0.01 \\
\hline Monte Carlo Sig. (2-tailed) & Sig. & $.011^{\mathrm{c}}$ \\
\cline { 2 - 3 } & $\begin{array}{l}99 \% \\
\text { Confidenc } \\
\text { e Interval }\end{array}$ & \\
\cline { 4 - 4 } & & \\
\hline
\end{tabular}

Source: Compiled from survey data (Using SPSS 20.0) $N=27$.

\section{COMPUTATION OF TEST STATISTICS \& DECISION OF CUSTOMER COST DIMENSION}

Since the data in consideration do not follow normality of distribution, Wilcoxon Sign-rank Test was applied to test the hypothesis considered in this Chapter - "There is no significant difference between the 'Degree of Customer Cost Dimension Expected' and the 'Degree of Customer Cost Dimension Experienced' of $4 \mathrm{C}$ based Marketing Mix with respect to Life Insurance in Guwahati”.

Wilcoxon Signed-rank test revealed that the null hypothesis i.e., "There is no significant difference between the 'Degree of Customer Cost Dimension Expected' and the 'Degree of Customer Cost Dimension Experienced' of Marketing Mix with respect to Life Insurance in Guwahati" is rejected [This is discernable from the Table No. 4. Stating differently there is a significant difference in the population between the 'Degree of Customer Cost Dimension Expected' and the 'Degree of Customer Cost Dimension Experienced'.

Table 4: Guwahati District Headquarter

Hypothesis Test Summary

\begin{tabular}{|c|c|c|c|c|}
\hline & Null Hypothesis & Test & Sig. & Decision \\
\hline 1 & $\begin{array}{l}\text { The median of differences between } \\
\text { Total of Customer Cost Expected } \\
\text { and Total of Customer Cost } \\
\text { Experienced equals O. }\end{array}$ & $\begin{array}{l}\text { Related- } \\
\text { Samples } \\
\text { Wilcoxon } \\
\text { Signed Rank } \\
\text { Test }\end{array}$ & .002 & $\begin{array}{l}\text { Reject the } \\
\text { null } \\
\text { hypothesis }\end{array}$ \\
\hline
\end{tabular}

Source: Compiled from survey data using SPSS 20.0

\section{CONCLUSION}

Given the Objectives, Hypothesis, and Methodology considered in this Chapter, it may concluded that there is significant difference between the 'Degree of Customer Cost Expected' and the 'Degree of Customer Cost Experienced' of 4C based Marketing Mix with respect to Life Insurance in Guwahati. The area-wise analysis also revealed similar results with respect to the each of the area considered in the study. Moreover, the Cross- Sectional analysis revealed that there is predominance of Insurance Investors with Negative Image; Investors with Positive and Neutral Image are in the minority. 
In addition, Wilcoxon Signed-rank test revealed that the null hypothesis i.e., "There is no significant difference between the 'Degree of Customer Cost Dimension Expected' and the 'Degree of Customer Cost Dimension Experienced' of Marketing Mix with respect to Life Insurance in Guwahati" is rejected. Stating differently there is a significant difference in the population between the 'Degree of Customer Cost Dimension Expected' and the 'Degree of Customer Cost Dimension Experienced'.

The findings if the current chapter suggests that for Customer focused product development, the Customer Cost (Price) is an important factor and must be factored into. The Actuary must develop the pricing based on the Gaps (Positive/ Neutral/ Negative) of investors, and the price must be simple, easy and affordable for the individual investors.

\section{REFERENCES}

[1] Allen, R Derek and Tanniru R. Rao,(2010), “Analysis of Customer Satisfaction Data”, New Age Publications, New Delhi.

[2] Ansari, H. (2006), "Insurance Reforms", IRDA Journal,Vol.IV,No.3, published by C.S.Rao on behalf of Insurance Regulatory and Development Authority.

[3] Bajpai G.N. (2005) “Insurance Industry India's Quest for cover”, The Journal of Insurance Institute of India,Vol.No.XXXII, July-December, S.J.Gidwani Publication.

[4] Banerjee, T.K (2004) "Insurance Regulations in India and Future Directions", The Journal of Insurance Institute of India, Vol. No.XXX, July- December, S.J.Gidwani Publication.

[5] Bhat, Ramesh (2005), "Insurance Industry in India: Structure, Performance, and Future Challenges", Insurance Industry in India, Vikalpa, Volume 30 , No 3, July - September 2005.

[6] Chopra, P.N(2009), "Managerial Economics”, Kalyani Publishers, New Delhi.

[7] Das, S.C (2007), "Cost Management Practices in Non-Life Insurance Companies: A Comparative Study”, www.insurance.com, dated 04-09-2007,January-June 2007.

[8] Dhanam(2008), “Insurance”, Business Magazine, June, Reg.no. KL/EKM/ 032/2006-08 RN 44620/87.

[9] Economic and Political Weekly (1971), "General Insurance Room for More Efficiency and Honesty”, 15 May 1971, Vol.VI, No.20.

[10] Economic and Political Weekly (1994), "Letters to Editor-Privatisation of Insurance Industry”, 9 July1994, Vol.XXIX,No.28.

[11] Kumar, Dinesh (2004), "Role Model of Branch Manager in the Emerging Scenario", Market Trends, Niseema Publishers, April-June, Vol.VI, No.2.

[12] Kumar, Jagendra (2004), "Changing Scenario of Insurance Industry”, The Journal of Insurance Institute of India,Vol.No.XXX, January- June, S.J.Gidwani Publication.

[13] Kumar,P S, Mohana ( 1998), “ A Hand Book on Research Methodology”, Right Publishers, Kudavechoor.

[14] Lautherborn, B. (1990). New Marketing: 4ps passes: C takes over. Advertising Age, 61(41), 26.

[15] Bhowal A., Bihani Pankaj: Image of Life Insurance Services-An Expectation-Experience Gap Analysis (Customer Cost Dimension). International Journal of Business and 
Management Invention ISSN (Online): 2319 -8028, ISSN (Print): 2319 -801X www.ijbmi.org, Volume 3, Issue 4, April. 2014 PP.42-47

[16] www.indistat.com

[17] www.inflibnet.com

[18] www.insurance.keralagov.in

[19] www.insurancetimes.com

[20] www.economicandpoliticalweekl.com

[21] www.irda.gov.in

[22] www.keralamonitor.com.

[23] www.newindiaassurance.com

[24] www.nicl.com

[25] www.orientalinsurance.com

[26] www.unitedindiainsurance.com 